Effect of nutrients on fermentation of pretreated wheat straw at very high dry matter content by Saccharomyces cerevisiae

Jørgensen, Henning

Published in:

Applied Biochemistry and Biotechnology

DOI:

10.1007/s12010-008-8456-0

Publication date:

2009

Document version

Early version, also known as pre-print

Citation for published version (APA):

Jørgensen, H. (2009). Effect of nutrients on fermentation of pretreated wheat straw at very high dry matter content by Saccharomyces cerevisiae. Applied Biochemistry and Biotechnology, 153(1-3), 44-57.

https://doi.org/10.1007/s12010-008-8456-0 
Appl Biochem Biotechnol (2009) 153:44-57

DOI 10.1007/s12010-008-8456-0

\section{Effect of nutrients on fermentation of pretreated wheat straw at very high dry matter content by Saccharomyces cerevisiae}

Henning Jørgensen

Forest and Landscape Denmark, University of Copenhagen, Rolighedsvej 23, DK-1958

Frederiksberg, Denmark

Corresponding author:

Henning Jørgensen

Rolighedsvej 23

DK-1958 Frederiksberg

Denmark

Tel: +45 35331704

E-mail: hnj@life.ku.dk 


\begin{abstract}
Wheat straw hydrolysate produced by enzymatic hydrolysis of hydrothermal pretreated wheat straw at a very high solids concentration of $30 \%$ dry matter $(w / w)$ was used for testing the effect of nutrients on their ability to improve fermentation performance of Saccharomyces cerevisiae. The nutrients tested were $\mathrm{MgSO}_{4}$ and nitrogen sources; $\left(\mathrm{NH}_{4}\right)_{2} \mathrm{SO}_{4}$, urea, yeast extract, peptone and corn steep liquor. The fermentation was tested in a separate hydrolysis and fermentation (SHF) process using a low amount of inoculum $\left(0.33 \mathrm{~g} \mathrm{~kg}^{-1}\right)$ and a non-adapted baker's yeast strain. A factorial screening design revealed that yeast extract, peptone, corn steep liquor and $\mathrm{MgSO}_{4}$ were the most significant factors in obtaining high a fermentation rate, high ethanol yield and low glycerol formation. The highest volumetric ethanol productivity was $1.16 \mathrm{~g} \mathrm{~kg}^{-1} \mathrm{~h}^{-1}$ and with an ethanol yield close to maximum theoretical. The use of urea or $\left(\mathrm{NH}_{4}\right)_{2} \mathrm{SO}_{4}$ separately, together or in combination with $\mathrm{MgSO}_{4}$ or vitamins did not improve fermentation rate and resulted in increased glycerol formation compared to the use of yeast extract. Yeast extract was the single best component in improving fermentation performance and a concentration of $3.5 \mathrm{~g} \mathrm{~kg}^{-1}$ resulted in high ethanol yield and a volumetric productivity of $0.6 \mathrm{~g} \mathrm{~kg}^{-1} \mathrm{~h}^{-1}$.
\end{abstract}




\section{Introduction}

Increased demand for ethanol for gasoline substitution together with growing debate about use of food sources for fuel production has put pressure on development of lignocellulose based ethanol plants. Economically viable ethanol production from lignocellulosic materials such as straw, corn stover, bagasse, wood and wood residues is still limited by a number of factors: price and performance of enzymes, efficient fermentation of all sugars (pentoses and hexoses), pretreatment costs and ability to handle lignocellulosic materials at high solids concentrations (1).

In the production of fuel ethanol from a source such as corn, operating the fermentation process at very high substrate concentrations has long been recognised as a way to increase productivity and reduce costs. The use of Very High Gravity (VHG) fermentations (mashes with more than 27\% (w/w) dissolved solids) improves plant productivity and process economics by reducing capital, energy, distillation and labour costs (2). Likewise, increasing the solids concentration in all steps in a lignocellulose based ethanol plant would improve process economics $(3,4)$. Operating lignocellulosic ethanol plants at similar sugar concentrations is technically a challenge. Considering the composition of typical lignocellulosic biomasses, in order to reach more than $25 \%(\mathrm{w} / \mathrm{w})$ sugar in the fermentation stage the process has to operate with $40-50 \%(\mathrm{w} / \mathrm{w})$ dry matter $(\mathrm{DM})$. Due to the high viscosity of these materials at such high solids concentrations it is difficult to obtain adequate mixing during the enzymatic hydrolysis step and the power consumption for stirring becomes high $(5,6)$. In pilot scale plants, a maximum substrate concentration of $15-20 \%$ solids in the hydrolysis step has often been reported (7). New reactor technologies for mixing of lignocellulosic materials have in recent years been developed, thereby enabling the possibility to hydrolyse and ferment materials with more than $30 \%$ initial solids concentration $(4,8)$.

Inhibitors generated in the pretreatment step are also a challenge in operating a lignocellulosic ethanol plant at high substrate concentrations. These inhibitors are acetic acid, sugar degradation products such as furfural and 5-hydroxymethyl furfural and small molecular phenolic compounds derived from lignin degradation $(9,10)$. Many studies on fermentability of pretreated lignocellulosic materials have been performed with dilute materials (corresponding to $2-5 \%$ solids concentration) and with increased solids concentration, the effect of inhibitors negatively impaired fermentation performance $(11,12,13)$. Removal of inhibitors by including a detoxification step is one possibility in order to improve fermentability of the material. This is not only a costly process step, but might also lead to loss of sugars (14). Another strategy is washing of the pretreated material, which may in addition improve the hydrolysis performance (15), although this requires viable strategies for utilising this dilute sugar stream (4). Adaptation of the fermenting microorganism has also proven to be very successful for improving fermentation performance in lignocellulosic materials $(11,16)$.

In VHG fermentations, the performance of Saccharomyces cerevisiae is affected by stress caused by high initial sugars concentrations, osmotic stress and high final ethanol concentrations $(17,18)$. It is generally recognised that fermentation performance (shorter lag phase, fast and complete fermentation) can be improved by presence of nutrients and especially a good nitrogen source $(18,19)$. Under anaerobic conditions, nitrogen is essential for cell proliferation $(20)$, and the rate of ethanol production is higher in actively growing yeast (2). Nitrogen starvation is known to result in growth arrest, drop in intracellular protein and decreased fermentation capacity (21). Free amino nitrogen (FAN) are excellent sources of nitrogen for the yeast and increasing FAN content by proteolytic degradation of protein present in mashes can increase fermentation performance (20). Many commercial enzyme preparations employed in degradation of starch for ethanol production therefore contain some proteolytic activity (22).

Hydrolysates from lignocellulosic materials are generally low in nutrients and nitrogen. Pretreated wheat straw contains only around $0.4 \%$ total nitrogen on a dry weight basis - mashes used in the 
traditional fuel ethanol production contains 10 times more $(18,23)$. Wheat straw might contain sufficient inorganic salts and trace metals to support the yeast, but during the pretreatment process some of these may be extracted (4). Considering the low availability of nutrients and the presence of inhibitors along with other factors known to cause stress in VHG fermentations, there should be a great potential for improving fermentation performance in fermentation of lignocellulosic materials at high solids concentrations by optimising the nutrients supplementation.

In this study, the effect of nutrients on the fermentation performance (fermentation rate, ethanol yield and by-products formation) of Saccharomyces cerevisiae in lignocellulosic hydrolysates at very high DM (above 20\% DM) was investigated. A hydrolysate was produced from pretreated wheat straw with 30\% (w/w) DM content. The resulting slurry was used in an SHF (Separate Hydrolysis and Fermentation) setup to screen six different nutrients/nitrogen sources, alone or in combination, for their ability to improve fermentation performance. The screening was done using a fractional factorial design followed by statistical analysis to identify the most significant factors and possible interaction effects. The six nutrients were selected from those commonly used for media formulation $(24,25)$, supplementation in fermentation of lignocellulosic hydrolysates $(11,23)$ and VHG-fermentation (18). These nutrients included simple nitrogen sources such as ammonium and urea and complex nutrients/nitrogen sources such as yeast extract, peptone and corn steep liquor. Additional experiments were performed to investigate the deficiency of nutrients in the wheat straw hydrolysate and to optimise the medium composition.

\section{Materials and Methods}

\section{Pretreated wheat straw}

Hydrothermal pretreatment was carried out at the Inbicon IBUS pilot plant at Skærbækværket in Skærbæk, Denmark $(4,26)$. Wheat straw (Triticum aestivum L.) was grown in Denmark. The straw was left to dry in the field and then pressed into big bales. The bales were stored dry at ambient temperature. The dry matter (DM) content was approximately $90 \%(\mathrm{w} / \mathrm{w})$. Straw was cut into pieces up to $6-10 \mathrm{~cm}$ long and fed to the pretreatment plant at a rate of $50 \mathrm{~kg} \mathrm{~h}^{-1}$ (approximately $45 \mathrm{~kg}$ dry matter per $\mathrm{h}$ ). The first step in the pretreatment was soaking in water at $80^{\circ} \mathrm{C}$ for $5-10$ min prior to being transported into the reactor. Residence time in the hydrothermal reactor averaged $12 \mathrm{~min}$. with the reactor temperature maintained at $195^{\circ} \mathrm{C}$ by injection of steam. No chemicals were added. The pretreatment was conducted at a water-straw ratio of 5:1 and the pretreated straw fibres were pressed to a high final dry matter (DM) content - in this case $44 \%(\mathrm{w} / \mathrm{w})$. The pretreated straw was collected in plastic bags containing $30-50 \mathrm{~kg}$ of material and stored at $4^{\circ} \mathrm{C}$ until use.

\section{Enzymatic hydrolysis}

The pretreated straw was hydrolysed in a specially designed hydrolysis reactor $(8)$. The pretreated material was adjusted to $30 \% \mathrm{DM}$ by addition of water. The $\mathrm{pH}$ was maintained at 4.8 to 5.0 by addition of $\mathrm{Na}_{2} \mathrm{CO}_{3}$. The material was heated to $50^{\circ} \mathrm{C}$ and enzyme corresponding to a loading of 5 FPU/g DM was added. A mixture of Celluclast 1.5 FG L and Novozym 188 in a weight ratio of 5:1 was used. The material was hydrolysed for $96 \mathrm{~h}$ with a mixing speed of $6.6 \mathrm{rpm}$ and the temperature was maintained at $50^{\circ} \mathrm{C}$. The hydrolysed material was stored at $-21^{\circ} \mathrm{C}$ in smaller portions until used for fermentation.

\section{Pre-cultivation of yeast}

A pure culture of baker's yeast (Saccharomyces cerevisiae) (De Danske Spritfabrikker, Denmark) was maintained on YPD-agar plates. Precultures were inoculated with one loopful of yeast into 500 
$\mathrm{ml}$ shake-flasks containing $200 \mathrm{ml}$ of defined mineral medium (24) with $20 \mathrm{~g} \mathrm{l}^{-1}$ of glucose. The glucose solution was autoclaved separately and the vitamin solution was sterilised by filtration. Precultures were grown on a rotary shaker at $150 \mathrm{rpm}$ and $30^{\circ} \mathrm{C}$ for two days. The culture medium was centrifuged for $15 \mathrm{~min}$ at $4200 \mathrm{~g}$ and the pellet was resuspended in $20 \%$ of the original volume in sterile $0.9 \% \mathrm{NaCl}$ solution. The cell mass concentration was determined according to Jørgensen et al. (21).

\section{Fermentation studies}

Fermentation experiments were performed in $100 \mathrm{ml}$ blue cap bottles with $66 \mathrm{~g}$ of hydrolysed material in the screening study (Table 1) and $72 \mathrm{~g}$ in all other studies. To maintain $\mathrm{pH}$ during the fermentation, trisodium citrate dihydrate was added at a concentration of $1.48 \mathrm{~g}$ per $100 \mathrm{~g}$ material. The $\mathrm{pH}$ was then adjusted to 5.5 by $1 \mathrm{M} \mathrm{NaOH}$ or $1 \mathrm{M} \mathrm{HCl}$. The bottles were then autoclaved at $125^{\circ} \mathrm{C}$ for $12 \mathrm{~min}$. Medium components were added to obtain the concentrations given by the experimental design (Table 1 and Table 2). Optimal yeast extract concentration was tested by adding yeast extract to obtain $0,0.5,1,2,3.5$ or $7 \mathrm{~g} \mathrm{~kg}^{-1}$. All experiments were performed in duplicate. The components were added as concentrated solutions: $\mathrm{MgSO}_{4} \cdot 7 \mathrm{H}_{2} \mathrm{O} 50 \mathrm{~g} \mathrm{l}^{-1},\left(\mathrm{NH}_{4}\right)_{2} \mathrm{SO}_{4}$ $100 \mathrm{~g} \mathrm{l}^{-1}$, urea $200 \mathrm{~g} \mathrm{l}^{-1}$, yeast extract $200 \mathrm{~g} \mathrm{l}^{-1}$, peptone $200 \mathrm{~g} \mathrm{l}^{-1}$. Corn steep liquor was used directly. The solutions were adjusted to approximately $\mathrm{pH} 5$ using $5 \mathrm{M} \mathrm{HCL}$ or $5 \mathrm{M} \mathrm{NaOH}$, autoclaved and added to bottles aseptically. Sterile water was added to ensure same final amount of material in all bottles. The fermentation was started by addition of $2 \mathrm{ml}$ of the pre-cultured yeast inoculum, corresponding to an inoculum size of $0.33 \mathrm{~g} \mathrm{~kg}^{-1}$ or $1.2 \mathrm{~g}$ yeast per $\mathrm{kg} \mathrm{DM}$. The total mass of material in the bottles was initially $80 \mathrm{~g}$. The bottles were closed by a rubber stopper with a syringe for ventilation of $\mathrm{CO}_{2}$ and the starting weight was recorded. A reference bottle was included without addition of yeast. The bottles were incubated at $32^{\circ} \mathrm{C}$ and shaking at $170 \mathrm{rpm}$. The weight of the bottles was measured at regular time points. The final composition of the fermentation broth was determined by HPLC analysis.

Table 1: Screening design used for testing main effect of medium components. Concentration in final medium in $\mathrm{g} \mathrm{kg}^{-1}$.

\begin{tabular}{lllllll}
\hline Run & $\mathrm{MgSO}_{4}$ & $\left(\mathrm{NH}_{4}\right)_{2} \mathrm{SO}_{4}$ & $\mathrm{Urea}$ & $\mathrm{CSL}^{\mathrm{a}}$ & $\mathrm{YE}^{\mathrm{b}}$ & Peptone \\
\hline $\mathrm{A}$ & 0 & 0 & 0 & 0 & 0 & 0 \\
$\mathrm{~B}$ & 0 & 0 & 0 & 5 & 5 & 5 \\
$\mathrm{C}$ & 0 & 0 & 5 & 0 & 5 & 5 \\
$\mathrm{D}$ & 0 & 0 & 5 & 5 & 0 & 0 \\
$\mathrm{E}$ & 0 & 5 & 0 & 0 & 5 & 0 \\
$\mathrm{~F}$ & 0 & 5 & 0 & 5 & 0 & 5 \\
$\mathrm{G}$ & 0 & 5 & 5 & 0 & 0 & 5 \\
$\mathrm{H}$ & 0 & 5 & 5 & 5 & 5 & 0 \\
$\mathrm{I}$ & 0.5 & 0 & 0 & 0 & 0 & 5 \\
$\mathrm{~J}$ & 0.5 & 0 & 0 & 5 & 5 & 0 \\
$\mathrm{~K}$ & 0.5 & 0 & 5 & 0 & 5 & 0 \\
$\mathrm{~L}$ & 0.5 & 0 & 5 & 5 & 0 & 5 \\
$\mathrm{M}$ & 0.5 & 5 & 0 & 0 & 5 & 5 \\
$\mathrm{~N}$ & 0.5 & 5 & 0 & 5 & 0 & 0 \\
$\mathrm{O}$ & 0.5 & 5 & 5 & 0 & 0 & 0 \\
$\mathrm{P}$ & 0.5 & 5 & 5 & 5 & 5 & 5 \\
$\mathrm{Q}$ & 0 & 0 & 5 & 0 & 0 & 0 \\
\hline${ }^{\mathrm{a}} \mathrm{CSL}-\mathrm{Corn}$ Steep Liquor & & & &
\end{tabular}


Table 2: Experimental design for testing simple nitrogen sources in combination with vitamins.

\begin{tabular}{lllll}
\hline Run & $\left(\mathrm{NH}_{4}\right)_{2} \mathrm{SO}_{4}$ & Urea & Biotin & Vitamin \\
\cline { 2 - 5 } & {$\left[\mathrm{g} \mathrm{kg}^{-1}\right]$} & {$\left[\mathrm{g} \mathrm{kg}^{-1}\right]$} & {$\left[\mathrm{mg} \mathrm{kg}^{-1}\right]$} & {$\left[\mathrm{ml} \mathrm{kg}^{-1}\right]$} \\
\hline $\mathrm{A}$ & 0 & 5 & 0 & 0 \\
$\mathrm{~B}$ & 0 & 5 & 0.0625 & 0 \\
$\mathrm{C}$ & 0 & 5 & 0 & 1.25 \\
$\mathrm{D}$ & 5 & 0 & 0 & 0 \\
$\mathrm{E}$ & 5 & 0 & 0.0625 & 0 \\
$\mathrm{~F}$ & 5 & 0 & 0 & 1.25 \\
$\mathrm{G}$ & 0 & 0 & 0.0625 & 0 \\
$\mathrm{H}$ & 0 & 0 & 0 & 1.25 \\
$\mathrm{I}$ & 0 & 0 & 0 & 0 \\
\hline a Vitamin solution also used for the defined preculture medium
\end{tabular}

\section{Analysis of straw samples}

Dry matter (total dry matter including soluble and insoluble solids) was determined using a Sartorius MA 30 moisture analyser at $105^{\circ} \mathrm{C}$.

Composition of the straw was analysed using two-step acid hydrolysis according to the procedure published by NREL (27). Before analysis, samples were dried at $45^{\circ} \mathrm{C}$ for one day. The straw samples were milled in a Braun coffee grinder.

\section{Analysis of sugar and ethanol on HPLC}

The content of monosaccharides (D-glucose, D-xylose and L-arabinose), organic acids (lactate and acetate), glycerol and ethanol was quantified on a Dionex Summit HPLC system equipped with a Shimadzu RI-detector. The separation was performed in a Phenomenex Rezex RHM column at $80^{\circ} \mathrm{C}$ with $5 \mathrm{mM} \mathrm{H}_{2} \mathrm{SO}_{4}$ as eluent at a flow rate of $0.6 \mathrm{ml} \mathrm{min}{ }^{-1}$. Samples were diluted approximately 10-fold with eluent, carefully mixed to extract all solubles into the liquid, and insoluble material was removed by centrifugation at $4200 \mathrm{~g}$ for $10 \mathrm{~min}$. The supernatant was filtered through a $0.45 \mu \mathrm{m}$ filter and analysed on HPLC. The dilution factor was determined by measuring the weight of the sample before and after dilution. This dilution procedure minimized the measurement error introduced when working with material with high content of insoluble solids (28). Results are reported as g per kg.

\section{Analysis of data}

The screening was done using a fractional factorial design. The experimental design and analysis of the data was made using the software JMP 6.0, SAS Institute.

\section{Results and discussion}

\section{Pretreatment and hydrolysis}

The pretreatment is based on a continuous reactor system using only steam and including an integrated washing step before the material is pressed to a higher solids concentration. During the pretreatment most of the hemicelluloses are removed from the material, but some degradation of sugars to furfural and 5-hydroxymethyl furfural takes place $(4,26)$. The composition of the pretreated material was: $27.5 \%$ lignin, $4.0 \%$ ash, $55.6 \%$ glucan (cellulose), $4.2 \%$ xylan, no arabinan was detected. The $9 \%$ residual is e.g. small amounts of protein, acetate and acid soluble lignin. The figures on the composition are in accordance with previous results obtained with straw (8). 
Since the pretreated material has a very high viscosity and still contains large fibre structures, it is not directly suitable for SSF (Simultaneous Saccharification and Fermentation) screening studies in small scale $(<100 \mathrm{ml})$ and above $10 \%(\mathrm{w} / \mathrm{w})$ DM. Mixing at 30\% (w/w) DM as in this study requires special equipment (8). The material was therefore hydrolysed separately for $96 \mathrm{~h}$ and the hydrolysed slurry was used for fermentation. In other words, the studies were performed as Separate Hydrolysis and Fermentation (SHF) studies.

After enzymatic hydrolysis for $96 \mathrm{~h}$, the material was liquefied and partially hydrolysed so it could be handled in smaller scale. The wheat straw hydrolysate contained $69.2 \mathrm{~g} \mathrm{~kg}^{-1}$ glucose, $5.4 \mathrm{~g} \mathrm{~kg}^{-1}$ xylose and $0.6 \mathrm{~g} \mathrm{~kg}^{-1}$ acetate. Since the material has a high content of insolubles and a density higher than water, the concentrations are reported as $\mathrm{g}$ per $\mathrm{kg}$ of material instead of $\mathrm{g}$ per 1 . The cellulose and xylan conversion was not very high, 41 and $43 \%$ respectively. However, a rather low enzyme loading of $5 \mathrm{FPU}(\mathrm{g} \mathrm{DM})^{-1}$ was used in order to minimise the influence from residual nutrients, amino acids and peptides as well as enzyme stabilising components all present in the enzyme preparation. For the purpose of this study, the initial glucose concentration was higher than what is frequently used in many fermentability studies of lignocellulosic hydrolysates $(8,11,16,23)$, and the hydrolysate would expose the yeast to stress caused by high sugar concentrations, osmotic stress, low nutrient content and various fermentation inhibitors present from the pretreatment step.

\section{Screening of nutrients}

Six nutrients/components typically used in fermentation media as nitrogen sources or as complex nutrients were tested in a fractional factorial design $\left(2^{6-2}\right)$ to validate the effect of the individual components and some 2-factor interactions (Table 1). Most components were tested at two levels; 0 and $5 \mathrm{~g} \mathrm{~kg}^{-1}$, except for $\mathrm{MgSO}_{4} \cdot 7 \mathrm{H}_{2} \mathrm{O}$, which was 10 -fold lower. The design was expanded by including urea alone as this is a cheap nitrogen source, and as reference the material was also tested without addition of any nutrients. Due to addition of nutrients solution, the wheat straw hydrolysate was diluted corresponding to an initial solids concentration of $25 \% \mathrm{DM}$.

Adaptation of yeast by preculturing on media containing hydrolysate with inhibitors is known to improve fermentation performance of yeast (11). Since this study was focused on testing the stimulating effect of various nutrients, this approach was not used. The yeast used in this study was a commercial baker's yeast strain precultured on a defined medium. To avoid transfer of nutrients from the preculture, cells were washed once before inoculation. A rather low inoculum size of 0.33 $\mathrm{g} \mathrm{kg}^{-1}$ was used (23). Use of a large inoculum size might mask the effect of inhibitors and stress (10) and limit the need for nutrient addition (19).

Initially, the experiment was performed without buffering of the material. This resulted in large changes in the $\mathrm{pH}$ during the fermentation. The final $\mathrm{pH}$ varied from 3.3 to 5.3 depending on nutrients added. It could therefore not be excluded that some of these more extreme $\mathrm{pH}$ values had an impact on the observed effects of nutrients. A test revealed that addition of citrate corresponding to $50 \mathrm{mM}$ could maintain the $\mathrm{pH}$ more constant. The end-pH in the experiments then varied from 4.5 to 5.3 .

The fermentation rate was monitored by following weight loss resulting from the $\mathrm{CO}_{2}$-production during the fermentations (Fig. 1). A great variation in performance of the yeast as a result of differences in nutrients addition could be observed. Without addition of nutrients the fermentation was very slow and not completed within $73 \mathrm{~h}$ (Fig. 1, A). Addition of urea or the combination of urea, $\left(\mathrm{NH}_{4}\right)_{2} \mathrm{SO}_{4}$ and $\mathrm{MgSO}_{4}$ did not significantly improve the fermentation rate (Fig. 1, $\mathrm{O}$ and Q). Residual glucose was detected after $73 \mathrm{~h}$ in $\mathrm{A}, \mathrm{O}$ and $\mathrm{Q}$. A shorter lag phase, fast and complete fermentation was obtained with six runs (Fig. 1, B, H, J, K, M, P), which had almost completed the fermentation within 24 hours. 


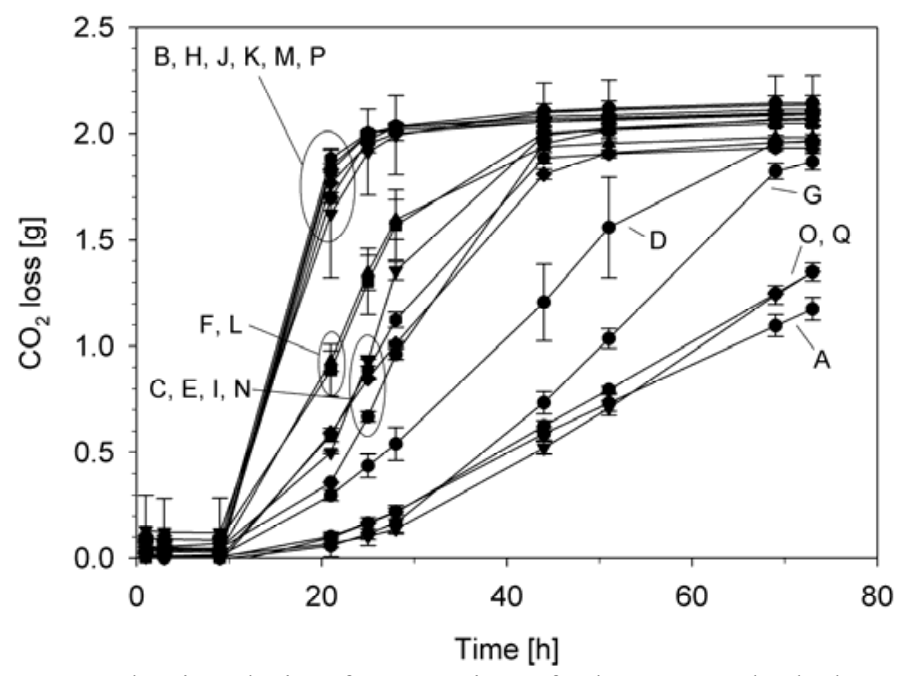

Figure 1: Time course of $\mathrm{CO}_{2}$-production during fermentation of wheat straw hydrolysate with addition of nutrients. The letters refer to the different runs as given in table 1.

Comparison of $\mathrm{CO}_{2}$-loss after $25 \mathrm{~h}$ was used as a simple way to statistically analyse differences between the various run and to evaluate the effect of nutrients on fermentation rate. The six runs $\mathrm{B}$, $\mathrm{H}, \mathrm{J}, \mathrm{K}, \mathrm{M}$ and $\mathrm{P}$ had significantly higher $\mathrm{CO}_{2}$-loss (on average $1.97 \pm 0.07 \mathrm{~g}$ ) after $25 \mathrm{~h}$ compared to the other runs, thereby indicating that these had the shortest lag phase and highest fermentation rate (Fig. 1). A general trend was that including yeast extract resulted in fast fermentations. This was also in agreement with the statistical model, which predicted that $\mathrm{MgSO}_{4}$, corn steep liquor, yeast extract $($ all $\mathrm{p}<0.001)$ and peptone $(\mathrm{p}=0.0068)$ contributed significantly to a high fermentation rate. Yeast extract was the factor contributing most to the model. Interestingly, although urea has shown good results in improving fermentation rate in wheat mash (18) it did not appear favourable in this study, which could be due to a general deficiency of important nutrients in the wheat straw hydrolysate.

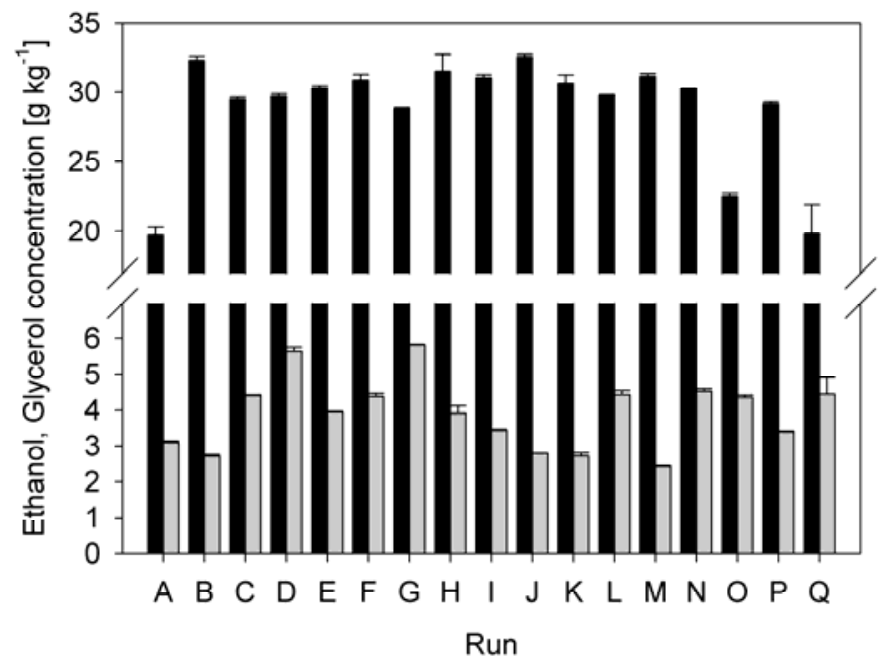

Figure 2: Ethanol (black) and glycerol (gray) concentrations in fermented wheat straw hydrolysate after $73 \mathrm{~h}$. The letters refer to the different runs as given in table 1 . 
The highest final ethanol concentration, $32.6 \mathrm{~g} \mathrm{~kg}^{-1}$, was obtained in run $\mathrm{J}$ (Fig. 2), which contained $\mathrm{MgSO}_{4}$, corn steep liquor and yeast extract. The runs B, E, F, H, I, J, K, M and $\mathrm{N}$ all ended with statistically the same ethanol concentration, on average $31.2 \pm 0.8 \mathrm{~g} \mathrm{~kg}^{-1}$, or $99 \%$ of maximum theoretical yield base on the initial glucose concentration in the hydrolysate. The yeast was therefore capable of efficiently fermenting the glucose in these cases. For the remaining runs, which resulted in complete fermentation, the fermentation efficiency was between 92 and $96 \%$ of maximum theoretical. Residual sugars and other components present in the complex nutrients, e.g. corn steep liquor, might have been fermented to ethanol, thereby increasing the apparent ethanol yield. Without addition of any nutrients the ethanol concentration ended at $19.8 \mathrm{~g} \mathrm{~kg}^{-1}$ or only $64 \%$ of theoretical maximum yield based on initial glucose. Although the fermentation was slow, correcting for the amount of consumed glucose resulted in a surprisingly high ethanol yield $-99 \%$ of theoretical.

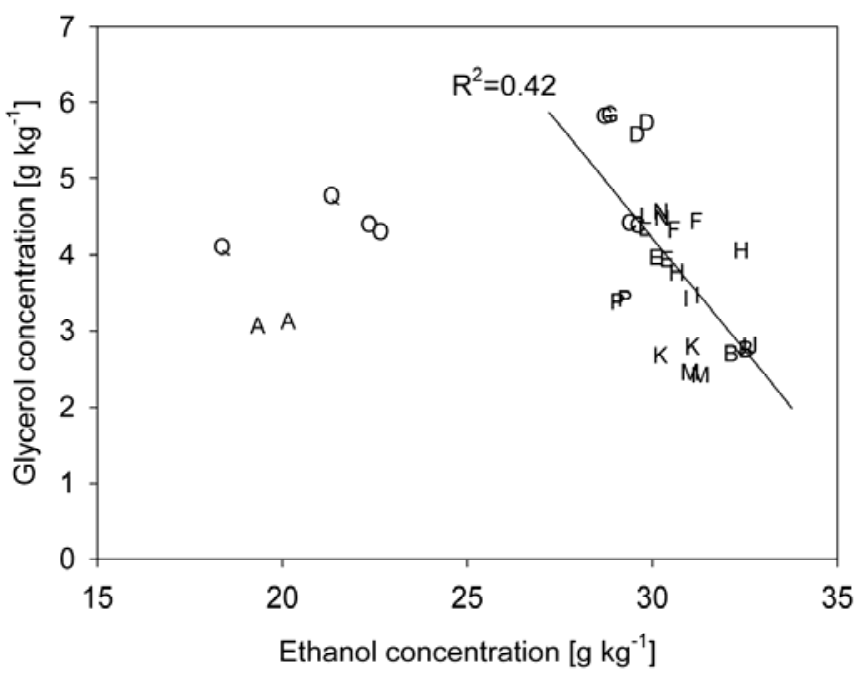

Figure 3: Ethanol concentration vs. glycerol concentration in fermented wheat straw hydrolysate after 73 h. Only values with ethanol concentrations above $25 \mathrm{~g} \mathrm{~kg}^{-1}$ are included in the linear regression. The letters refer to the different runs as given in table 1.

The production of glycerol was also measured (Fig. 2). The lowest level of glycerol was obtained in run $\mathrm{M}, 2.4 \mathrm{~g} \mathrm{~kg}^{-1}$, which resulted in $31.2 \mathrm{~g} \mathrm{~kg}^{-1}$ of ethanol. The highest glycerol concentration was obtained in run $\mathrm{G}, 5.8 \mathrm{~g} \mathrm{~kg}^{-1}$, which was one of the slow fermentations that resulted in complete fermentation (no residual glucose after 73 h) (Fig. 1). Run $G$ was characterised by a low final ethanol concentration, $28.8 \mathrm{~g} \mathrm{~kg}^{-1}$ or only $92 \%$ of maximum theoretical. Plotting final ethanol concentration vs. glycerol concentration revealed no correlation between glycerol and ethanol yield (Fig. 3), although it seems likely that lower ethanol yield is caused by higher production of glycerol. However, a group of four runs $(\mathrm{B}, \mathrm{J}, \mathrm{K}, \mathrm{M})$ with the lowest glycerol formation were among those with the highest fermentation rate (highest $\mathrm{CO}_{2}$ loss after $25 \mathrm{~h}$ ). It has previously been shown that the nitrogen source has an influence on anaerobic growth and product formation. Under anaerobic conditions, glycerol production functions to maintain the redox-balance when the yeast is synthesising amino acids. Supplementing the medium with free amino acids will therefore potentially reduce the glycerol formation. Compared to a medium with ammonium as nitrogen source, growth on medium containing a mixture of amino acid resulted in $50 \%$ lower glycerol formation and $14 \%$ higher ethanol production (25). The inclusion of a complex nitrogen source also reduced the fermentation time from 14 to $8 \mathrm{~h}$, which is in good agreement with the results obtained in this study. 
The statistical model predicted that yeast extract was the most important significant factor for obtaining low glycerol formation, followed by $\mathrm{MgSO}_{4}$. Urea and $\left(\mathrm{NH}_{4}\right)_{2} \mathrm{SO}_{4}$ significantly contributed to the model by increasing the glycerol formation. Results from the screening experiment revealed that simple nitrogen sources such as $\left(\mathrm{NH}_{4}\right)_{2} \mathrm{SO}_{4}$ or urea would not result in optimum fermentation performance under the given conditions. Even the combination of urea, $\left(\mathrm{NH}_{4}\right)_{2} \mathrm{SO}_{4}$ and $\mathrm{MgSO}_{4}$ resulted in poor fermentation performance. Similar to what has been found previously for VHG fermentation of corn or wheat mashes, free amino acids such as from yeast extract can substantially reduce the fermentation time $(18,20)$. Free amino acids seemed to be the most efficient in alleviating stress or lack of nutrients in wheat straw hydrolysate.

In the statistical model $\mathrm{MgSO}_{4}$ was found to have a positive effect on performance in terms of both fermentation time and ethanol formation, which is in accordance with observations by others (29). Inorganic ions important for growth and fermentation, such as $\mathrm{Mg}^{2+}, \mathrm{Zn}^{2+}, \mathrm{Co}^{2+}, \mathrm{Mo}^{2+}$ and $\mathrm{Mn}^{2+}$, are only required in small concentrations, typically $\mu \mathrm{M}$ to $\mathrm{mM}$ range (30), and could possibly be present in sufficient amounts in wheat straw. As a part of the pretreatment process employed in this study, many salts and ions are removed from the straw fibres (4). The $\mathrm{Mg}^{2+}$-content in a similar wheat straw hydrolysate has been measured to around $1 \mathrm{mM}$ (Inbicon, personal communication). Since the optimal $\mathrm{Mg}^{2+}$ concentration has been reported to be 2-4 $\mathrm{mM}$ (30), the concentration of $\mathrm{Mg}^{2+}$ is probably not optimal for good performance of the yeast. Supplementation with $\mathrm{MgSO}_{4}$ in this study corresponded to $2.1 \mathrm{mM} \mathrm{Mg}$, which all together should ensure sufficient $\mathrm{Mg}^{2+}$. It is possible that other important ions as listed above are also present in suboptimal concentrations and this could be the objective for further investigation.

\section{Effect of urea together with vitamins}

Urea is an inexpensive nitrogen source and has also been found in some studies to stimulate yeast performance in VHG fermentations (18). Ammonium is also frequently used as inexpensive nitrogen source and with the advantage that it can also function as a base for $\mathrm{pH}$-adjustment. In this screening study no positive effect of urea or ammonium was observed in the applied concentrations. One reason could be the lack of other important nutrients or vitamins. The combination of urea, $\left(\mathrm{NH}_{4}\right)_{2} \mathrm{SO}_{4}$ and $\mathrm{MgSO}_{4}$ (Fig. 1, run O) revealed that $\mathrm{MgSO}_{4}$ was not solely sufficient to ensure high fermentation performance. Addition of biotin to the medium has in some studies resulted in improved fermentation performance (31). Experiments with urea and $\left(\mathrm{NH}_{4}\right)_{2} \mathrm{SO}_{4}$ was therefore conducted, in which either biotin $\left(0.0625 \mathrm{mg} \mathrm{kg}^{-1}\right)$ or vitamin solution $\left(1.25 \mathrm{ml} \mathrm{kg}{ }^{-1}\right)$ was also added (Table 2). The vitamin solution was similar to the one employed in the formulation of the defined medium and also contained biotin. As fewer nutrients were added compared to the screening study, the dilution of wheat straw hydrolysate corresponded to an initial solids concentration of $27 \% \mathrm{DM}$.

Supplementing the wheat straw hydrolysate with biotin did not statistically improve fermentation rate (as given by $\mathrm{CO}_{2}$-loss after $48 \mathrm{~h}$ ), whereas addition of vitamin solution had $10 \%$ higher $\mathrm{CO}_{2}$ production (Fig. 4). In all three cases there was residual glucose left after $95 \mathrm{~h}$ of fermentation indicating a very poor fermentation performance. Again, there was slightly less glucose left with addition of vitamin solution. There was no statistically difference in final ethanol concentration with or without addition of biotin, but the addition of vitamin solution resulted in significantly higher final ethanol concentration $\left(21.9 \mathrm{~g} \mathrm{~kg}^{-1}\right)$, corresponding to $70 \%$ of the maximum theoretical ethanol yield based on initial glucose (Fig. 4). Based on consumed glucose, the ethanol yield was $90 \%$ of maximum theoretical.

Addition of either urea or $\left(\mathrm{NH}_{4}\right)_{2} \mathrm{SO}_{4}$ did not significantly improve the fermentation rate $\left(\mathrm{CO}_{2}\right.$-loss after $48 \mathrm{~h}$ ) compared to without any addition (Fig. 4), but less than $2 \mathrm{~g} \mathrm{~kg}^{-1}$ of glucose was remaining after $93 \mathrm{~h}$ revealing that fermentation performance was indeed improved. The ethanol yield was therefore also significantly increased by around 35\% (Fig. 4). Additional supplementation 
with biotin or vitamin solution resulted in no further increase in ethanol yield. All six runs with urea and $\left(\mathrm{NH}_{4}\right)_{2} \mathrm{SO}_{4}$, with and without supplementation with biotin or vitamin solution, had statistically the same final ethanol concentration.

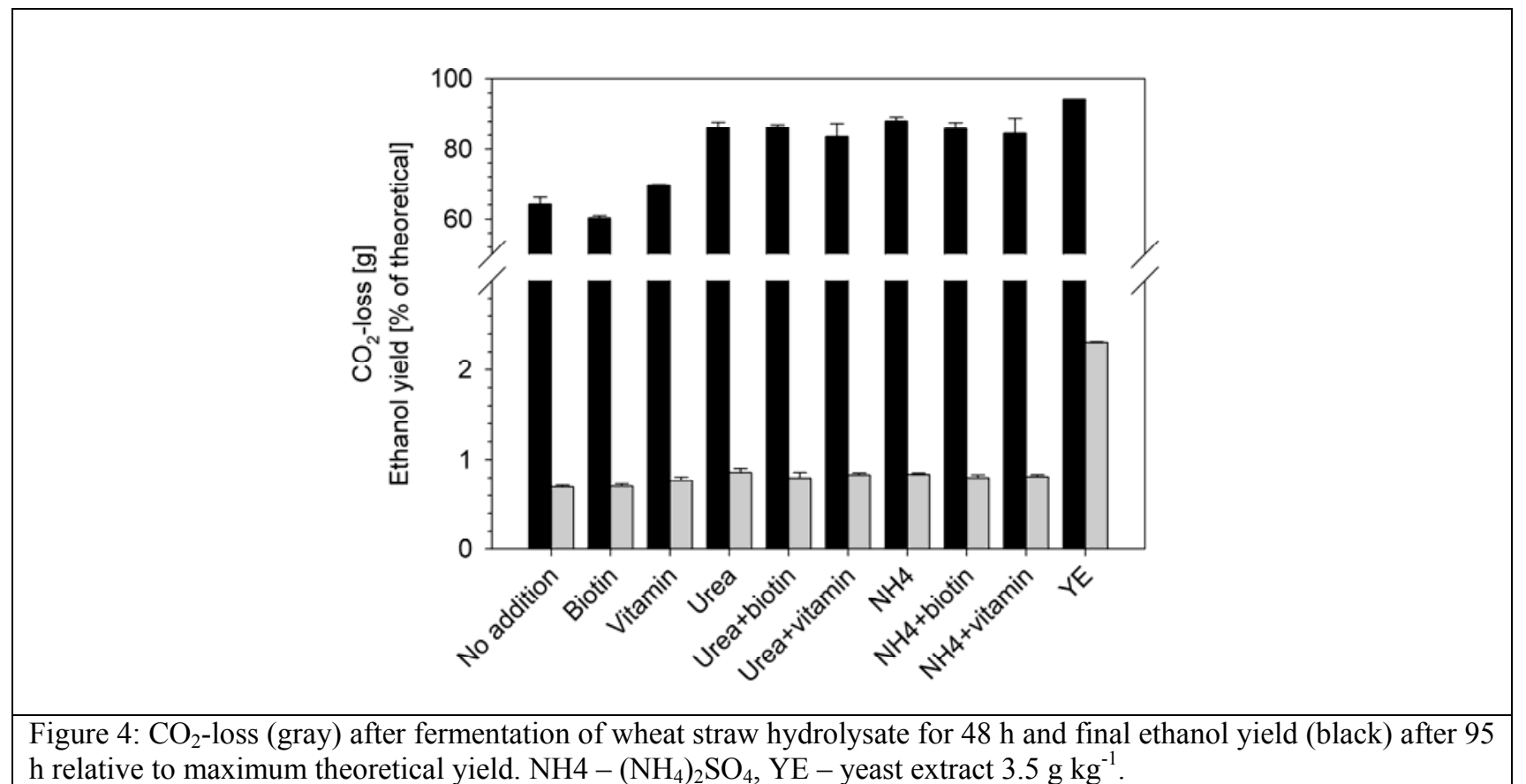

Glycerol formation was rather high in experiments with urea and $\left(\mathrm{NH}_{4}\right)_{2} \mathrm{SO}_{4}, 5.2$ and $4.8 \mathrm{~g} \mathrm{~kg}^{-1}$ respectively. In both cases, addition of vitamin solution increased glycerol formation by 6 and $23 \%$, respectively. This could indicate that vitamin addition stimulated biomass formation (synthesis of amino acids) and therefore more NADH had to be oxidised with the consequence of an increased flux towards glycerol (25). Biotin alone resulted in no increase in glycerol formation.

For comparison, use of $3.5 \mathrm{~g} \mathrm{~kg}^{-1}$ yeast extract resulted in substantially faster fermentation - almost three-fold more $\mathrm{CO}_{2}$ was produced after $48 \mathrm{~h}$ (Fig. 4). Final ethanol yield (94\% of theoretical) was on average $10 \%$ higher than with the use of urea or $\left(\mathrm{NH}_{4}\right)_{2} \mathrm{SO}_{4}$ with/without vitamins. This could be explained by a much lower glycerol formation with the use of yeast extract $\left(3.7 \mathrm{~g} \mathrm{~kg}^{-1}\right)$. Again, availability of free amino acid appears to be very important for reducing production of by-products and thereby directing a larger fraction of the metabolised carbon towards ethanol.

Results reveal that wheat straw hydrolysate is very deficient in most nutrients required by yeast. Some nutrients are removed during the pretreatment and vitamins are most likely completely lost during the high temperature pretreatment. The combination of a simple nitrogen source together with vitamins was however not enough to obtain an effect similar to yeast extract.

\section{Optimising concentration of yeast extract}

Yeast extract proved to be very efficient for increasing fermentation rate, but yeast extract is an expensive additive, which should at least be added in smallest possible amounts in order to make the process economical viable (18). Therefore, the effect of yeast extract alone was tested in concentrations between 0 and $7 \mathrm{~g} \mathrm{~kg}^{-1}$. The experiment revealed that increasing the yeast extract concentration gradually increased the fermentation rate (Fig. 5). After approximately $50 \mathrm{~h}$, the fermentation was completed with addition of 3.5 or $7 \mathrm{~g} \mathrm{~kg}^{-1}$ of yeast extract.

Final ethanol concentration in the wheat straw hydrolysate was not significantly affected by the concentration of yeast extract, on average $30.3 \pm 0.6 \mathrm{~g} \mathrm{~kg}^{-1}$, corresponding to $96 \%$ of maximum 
theoretical yield. Only fermentation without addition of yeast extract had a lower ethanol production, $20.3 \mathrm{~g} \mathrm{~kg}^{-1}$ or $66 \%$ of maximum theoretical yield.

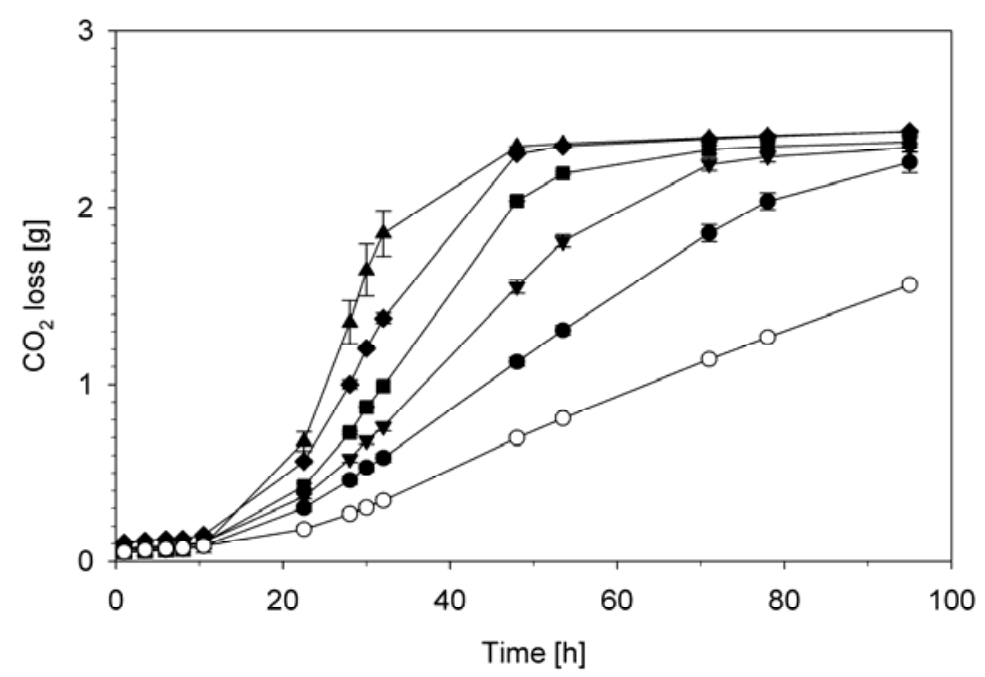

Figure 5: Time course of $\mathrm{CO}_{2}$-production during fermentation of wheat straw hydrolysate with addition of yeast extract in the concentrations $0(\mathrm{O}), 0.5(\mathbf{O}), 1(\boldsymbol{\nabla}), 2(\boldsymbol{\square}), 3.5 \bullet$ and $7(\boldsymbol{\Delta}) \mathrm{g} \mathrm{kg}^{-1}$.

Although there was no significant difference in ethanol concentration, the glycerol concentration gradually decreased as the yeast extract concentration increased. With addition of $0.5 \mathrm{~g} \mathrm{~kg}^{-1}$ yeast extract the glycerol concentration reached $4.3 \mathrm{~g} \mathrm{~kg}^{-1}$, and this dropped to $3.5 \mathrm{~g} \mathrm{~kg}^{-1}$ with addition of $7 \mathrm{~g} \mathrm{~kg}^{-1}$.

Supplementation with $3.5 \mathrm{~g} \mathrm{~kg}^{-1}$ yeast extract resulted in almost similar fermentation rate as using 7 $\mathrm{g} \mathrm{kg}^{-1}$, as based on the $\mathrm{CO}_{2}$-production profiles (Fig. 5), and final yields of ethanol were not significantly affected by the amount of yeast extract supplemented to the wheat straw hydrolysate. Using $3.5 \mathrm{~g} \mathrm{~kg}^{-1}$ yeast extract therefore seems optimal, when the high price of yeast extract is taken into consideration. Further reduction to $2 \mathrm{~g} \mathrm{~kg}^{-1}$ resulted in somewhat longer fermentation time, from around 50 to $78 \mathrm{~h}$, before the fermentation was completed (Fig. 5).

\section{Nutrients supplementation in commercial processes}

This study revealed that there is a potential for optimising hydrolysate composition from wheat straw to improve fermentation performance (rate, maximum ethanol yield and minimum glycerol formation) of Saccharomyces cerevisiae. Many other lignocellulosic materials are most likely as deficient in important nutrients and nitrogen as the wheat straw tested in this study, although some feedstocks may be better than others. Besides feedstock, choice of pretreatment method will also strongly influence nutrient content in the resulting material $(4,16)$. However, a number of factors are influencing the importance of low nutrient and nitrogen content in the hydrolysate on the fermentation performance. Among these are 1) solids concentration (DM), 2) size of yeast inoculum, 3) yeast strain and adaptation and 4) process configuration (SSF or SHF).

Operating at very high solids content, such as $25-27 \%$ DM in this study, will certainly increase the stress applied on the yeast. Depending on the pretreatment process, 10 to 20\% DM has often been reported as the limit for successful ethanol fermentation from lignocellulosic materials $(11,12)$. The effect of fermentation inhibitors, e.g. long lag phase and slow fermentation, can to some extent be overcome by increasing the inoculum size (10), by selecting more robust strains or by adaptation of the strain in medium containing the inhibitors (11). In this study non-adapted yeast and a very low inoculum size compared to most other studies was selected in order to clearly study the possible 
effect of nutrients. In practice, using a very low inoculum size would also benefit the process economically $(3,23)$.

Although the conditions selected in this study were less than ideal for the fermenting organism, it was possible to obtain ethanol yields near the theoretical maximum when nutrients were added. In the best case (run J), the volumetric ethanol productivity in the exponential phase ( 9 to $28 \mathrm{~h}$ ) was estimated to $1.6 \mathrm{~g} \mathrm{~kg}^{-1} \mathrm{~h}^{-1}$, which is well above $1 \mathrm{~g} \mathrm{l}^{-1} \mathrm{~h}^{-1}$ reported to be an important economical threshold (32). Including even the lag phase resulted in an overall ethanol productivity of $1.16 \mathrm{~g} \mathrm{~kg}^{-}$ ${ }^{1} \mathrm{~h}^{-1}$, which is still high for a lignocellulosic material (16). However, in this case the wheat straw hydrolysate was supplemented with corn steep liquor, yeast extract and $\mathrm{MgSO}_{4}$, which is not economically feasible. Employing only yeast extract in the optimal concentration of $3.5 \mathrm{~g} \mathrm{~kg}^{-1}$ resulted in a volumetric productivity of $0.8 \mathrm{~g} \mathrm{~kg}^{-1} \mathrm{~h}^{-1}$ in the exponential phase $\left(0.6 \mathrm{~g} \mathrm{~kg}^{-1} \mathrm{~h}^{-1}\right.$ including the lag phase) and an ethanol yield of $96 \%$. This is comparable to other studies on pretreated corn stover supplemented with DDGS (Distillers Dry Grain with Solubles) hydrolysate (16).

Commercial scale lignocellulosic ethanol production at very high solids concentration will should be operated in SSF mode due to severe product inhibition of enzymes in the late stage of hydrolysis in SHF (1). In SSF, the fermentation rate is to be determined by the rate of the enzymes rather than the fermenting microorganism. The requirements for optimisation of the medium to obtain high fermentation performance, especially fermentation rate, may consequently be less strict. Pretreated wheat straw has successfully been fermented to high ethanol concentrations in SSF without nutrient addition $(4,8)$. Other issues specific for SSF are the typically much longer process times in combination with very high final ethanol concentrations. In a previous study using material similarly to the ones used in this study, it was found that although glucose liberated during a prehydrolysis period was quickly fermented at solids concentrations up to $40 \% \mathrm{DM}$ without nutrients addition, glucose accumulation was observed during the late stage of SSF (8). In other studies, yeast viability was found to be lost after 4 days when the initial solids loading was above $20 \% \mathrm{DM}$ (5). This indicates that even in SSF there might be a need for or advantage of nutrient addition and optimisation.

An important issue is also the costs of nutrient addition. Yeast extract was clearly the most successful additive in improving fermentation performance, but it is also the most expensive of the tested nutrients (18). Corn steep liquor is a cheaper source of nitrogen and other nutrients, but this study revealed that it had to be added in higher amounts in order to give similar effect as yeast extract. Alternative complex nutrient and nitrogen sources such as DDGS hydrolysates (containing also some yeast residues) (16) or grass juices (33) could be considered. The increased amounts of DDGS arising from the expanding fuel ethanol industry (34) could make DDGS hydrolysates a cheap and attractive nutrient supplement. Simple nitrogen sources such as urea and $\left(\mathrm{NH}_{4}\right)_{2} \mathrm{SO}_{4}$ had some effect under the tested concentrations, but would probably have to be used in higher amounts and/or combined with other nutrients. Combined with other possibilities such as increased inoculum size, strain adaptation and using SSF, a comprehensive techno-economic study is therefore needed to find the most viable solution for a given process and feedstock.

\section{Acknowledgment}

Technician Britta Skov is gratefully acknowledged for assisting with the experimental work. Inbicon is thanked for supplying the pretreated material and Novozymes is thanked for supplying enzymes. The work was financially supported by Energinet.dk PSO contract 2006-1-6412 and other partners in the project, Inbicon, Risø-DTU and BioCentrum-DTU are thanked for their collaboration. 


\section{Refrences}

1. Jørgensen, H., Kristensen, J. B., and Felby, C. (2007), Biofuels, Bioprod. Bioref. 1, 119-134.

2. Bayrock, D. P., Ingledew, W. M. (2001), J. Ind. Microbiol. Biotechnol. 27, 87-93.

3. Wingren, A., Galbe, M., and Zacchi, G. (2003), Biotechnol. Prog. 19, 1109-1117.

4. Larsen, J., Petersen, M. Ø., Thirup, L., Li, H. W., and Iversen, F. K. (2008), Chem. Eng. Technol. 31, 765-772.

5. Mohagheghi, A., Tucker, M., Grohmann, K., and Wyman, C. (1992), Appl. Biochem. Biotechnol. 33, 67-81.

6. Fan, Z. L., South, C., Lyford, K., Munsie, J., van Walsum, P., and Lynd, L. R. (2003), Bioprocess Biosyst. Eng. 26, 93-101.

7. Tolan, J. S. (2002), Clean Techn. Environ. Policy 3, 339-345.

8. Jørgensen, H., Vibe-Pedersen, J., Larsen, J., and Felby, C. (2007), Biotechnol. Bioeng. 96, 862870.

9. Larsson, S., Palmqvist, E., Hahn-Hagerdal, B., Tengborg, C., Stenberg, K., Zacchi, G., and Nilvebrant, N. O. (1999), Enzyme Microb. Technol. 24, 151-159.

10. Palmqvist, E., Hahn-Hägerdal, B. (2000), Bioresour. Technol. 74, 25-33.

11. Alkasrawi, M., Rudolf, A., Liden, G., and Zacchi, G. (2006), Enzyme Microb. Technol. 38, 279286.

12. Varga, E., Klinke, H. B., Réczey, K., and Thomsen, A. B. (2004), Biotechnol. Bioeng. 88, 567574.

13. Linde, M., Galbe, M., and Zacchi, G. (2007), Enzyme Microb. Technol. 40, 1100-1107.

14. Yang, B., Wyman, C. E. (2008), Biofuels, Bioprod. Bioref. 2, 26-40.

15. Tengborg, C., Galbe, M., and Zacchi, G. (2001), Enzyme Microb. Technol. 28, 835-844.

16. Lau, M. W., Dale, B. E., and Balan, V. (2008), Biotechnol. Bioeng. 99, 529-539.

17. Devantier, R., Scheithauer, B., Villas-Boas, S. G., Pedersen, S., and Olsson, L. (2005), Biotechnol. Bioeng. 90, 703-714. 
18. Jones, A. M., Ingledew, W. M. (1994), Proc. Biochem. 29, 483-488.

19. Casey, G. P., Magnus, C. A., and Ingledew, W. M. (1984), Appl. Environ. Microbiol. 48, 639646.

20. Thomas, K. C., Ingledew, W. M. (1990), Appl. Environ. Microbiol. 56, 2046-2050.

21. Jørgensen, H., Olsson, L., Rønnow, B., and Palmqvist, E. A. (2002), Appl. Microbiol. Biotechnol. 59, 310-317.

22. Lewis, S. M.(1996), in Industrial Enzymology, (Godfrey, T. and West, S., ed.), Stockton Press, New York pp. 12-48.

23. Linde, M., Jakobsson, E.-L., Galbe, M., and Zacchi, G. (2008), Biomass Bioenerg. 32, 326-332.

24. Verduyn, C., Postma, E., Scheffers, W. A., and Vandijken, J. P. (1992), Yeast 8, 501-517.

25. Albers, E., Larsson, C., Liden, G., Niklasson, C., and Gustafsson, L. (1996), Appl. Environ. Microbiol. 62, 3187-3195.

26. Thomsen, M. H., Thygesen, A., Jørgensen, H., Larsen, J., Christensen, B. H., and Thomsen, A. B. (2006), Appl. Biochem. Biotechnol. 129-132, 448-460.

27. Sluiter, A., Hames, B., Ruiz, R., Scarlata, C., Sluiter, J., Templeton, D., and Crocker, D. (2008), National Renewable Energy Laboratory, Golden, CO, USA, Technical Report NREL/TP-51042618. Available from http://www.nrel.gov/biomass/pdfs/42618.pdf

28. Kristensen, J. B., Felby, C., and Jørgensen, H. (2008), Appl. Biochem. Biotechnol. http://dx.doi.org/10.1007/s12010-008-8375-0.

29. Wang, F.-Q., Gao, C.-J., Yang, C.-Y., and Xu, P. (2007), Biotechnol. Lett. 29, 233-236.

30. Jones, R. P., Greenfield, P. F. (1984), Proc. Biochem. 19, 48-\&.

31. Brandberg, T., Karimi, K., Taherzadeh, M. J., Franzen, C. J., and Gustafsson, L. (2007), Biotechnol. Bioeng. 98, 80-90.

32. Dien, B. S., Cotta, M. A., and Jeffries, T. W. (2003), Appl. Microbiol. Biotechnol. 63, 258-266.

33. Thomsen, M. H. (2005), Appl. Microbiol. Biotechnol. 68, 598-606.

34. Brehmer, B., Bals, B., Sanders, J., and Dale, B. (2008), Biotechnol. Bioeng. 101, 49-61. 